\title{
Market reaction to tender and private offers on the JSE
}

\author{
N. Wesson ${ }^{a \star}$, C. Muller ${ }^{\mathrm{b}}$ and M. Ward ${ }^{\mathrm{b}}$ \\ anniversity of Stellenbosch Business School, PO Box 610, Bellville, 7535, South Africa \\ ${ }^{\mathrm{b}}$ Gordon Institute of Business Science, University of Pretoria, South Africa \\ *To whom all correspondence should be addressed \\ n.wesson@sun.ac.za
}

\begin{abstract}
Investors can benefit when incorporating the information-signalling effect of share repurchases in their investment strategies. Previous South African studies on open market share repurchases confirmed the globally observed signallingeffect, but found open market share repurchases not to be the outright favoured share repurchase type in this country - as is the case globally. The present study is the first to examine the market reaction to the preferred share repurchase type, namely specific (or tender and private offers) share repurchases, in the South African regulatory environment. Abnormal returns were calculated using a 12-parameter benchmark over a four-year event window, for share repurchases announced from 1999 to 2009. Pro rata tender offers were found not to possess information-signalling benefits, but significant excess returns subsequent to the announcement date were reported for the two private offer types (namely other specific offers and the repurchase by the holding company of shares held by subsidiaries). The other specific offers were found to possess significant information-signalling benefits - especially over the long term and in respect of value companies.
\end{abstract}

\section{Introduction}

The explanation most commonly offered in literature for the repurchasing of shares is that managers use this action to signal to the market their optimism about their company's prospects. Positive abnormal returns subsequent to a share repurchase announcement are well documented and support the information-signalling theory (Ikenberry, Lakonishok, \& Vermaelen, 1995; Manconi, Peyer, \& Vermaelen, 2013; Peyer \& Vermaelen, 2007; Yook, 2010). Investment strategies based on the benefits to be derived from the information-signalling effect of share repurchases, however, need to incorporate the windows of opportunity and the different types of share repurchases involved.

There are essentially three types of share repurchases: open market, tender offers and private offers. The open market share repurchase is the globally preferred method representing more than $90 \%$ of share repurchase value in the United States of America (US) and the United Kingdom (UK) (Banyi, Dyl, \& Kahle, 2008: 460; Fairchild \& Zang, 2005; Grullon \& Michaely, 2004: 651). The preference for open market share repurchases explains the global research focus on this type of share repurchase.

The US has recorded the highest share repurchase activity to date when compared to other countries, with the UK and Japan showing the next highest (Kim, Schremper, \& Varaiya, 2004: 5; Manconi et al., 2013; Stonham, 2002: 37; Van Rixtel \& Villegas, 2015). Although non-US companies generally follow the same market reaction patterns as documented in US research, it is expected that cross-country differences in the quality of corporate governance and regulatory differences may lead to variations in reported abnormal returns subsequent to share repurchase announcements (Manconi et al., 2013).

In South Africa, share repurchases were allowed as from 1 July 1999. South African share repurchase activity has not yet reached the levels of US share repurchases, but a strong increase in share repurchase activity since 2005 has been observed (Wesson, Bruwer, \& Hamman, 2015). The unique South African regulatory environment has, however, resulted in the open market share repurchase type not being the favoured approach for companies listed on the Johannesburg Stock Exchange Ltd (JSE). Only about $43 \%$ of South African share repurchase value is executed through the open market and, owing to the $3 \%$ announcement rule of the JSE Listings Requirements, only about 59\% of the open market share repurchase value is announced via the Security Exchange News Service (SENS) (Wesson et al., 2015). South African studies on the market reaction to open market share repurchase announcements by JSE-listed companies found support for the information-signalling theory (Bhana, 2007; Pienaar \& Krige, 2012; Wesson, Muller, \& Ward, 2014).

In South Africa there are essentially one tender offer type (namely pro rata offers) and two types of private offers (namely other specific offers and the repurchase by the holding company of shares held by subsidiaries) (Bester, Wesson, \& Hamman, 2010). South African studies have not yet addressed the information-signalling effect of tender and private offer share repurchase announcements by JSE-listed companies.

The present study is the first South African study on the market reaction to tender and private offers by JSE-listed companies. The results of this study will better equip market 
participants in deciding whether and when to act in response to a JSE-listed company's announcement to repurchase shares via the preferred South African share repurchase method.

\section{Literature review}

A company's managers are better informed than outside shareholders about the true value of the company, and this information asymmetry may lead to companies being priced below their intrinsic value. Share repurchase plans therefore convey a credible sign from management that company shares are undervalued (Miller \& Rock, 1985). The information-signalling potential of a share repurchase announcement, however, depends on the type of share repurchase involved. Open market share repurchase announcements are non-committal, as opposed to tender offers and private offers, which generally need to be executed once the terms of the arrangement have been agreed on (Bester, et al., 2010). Literature therefore generally reports higher initial (or short-term) market reactions to share repurchase types where the announcement represents a firm commitment to repurchase (Yook, 2010). Ikenberry et al. (1995) developed the underreaction theory which postulates that the market treats the initial announcement, especially in respect of open market share repurchases, with scepticism; and it is mainly over the long term, and in particular for value shares (undervalued shares), that the excess return is observed. The information-signalling theory therefore entails two elements: the short-term effect (or traditional signalling theory) and the long-term effect (or underreaction theory).

Different terminologies are used in different jurisdictions when referring to the three generally accepted share repurchase types (namely open market, tender offers and private offers). The open market repurchase type, for instance, refers to the 'on-market' repurchase in some jurisdictions, and in South Africa it refers to the 'general repurchase'. The tender offer type is called the 'equal access repurchase' in some jurisdictions, and in many jurisdictions there are different categories of tender offers, depending on the nature of these offers. In the US there are essentially two types of tender offers: the fixed price tender offer and the Dutch auction tender offer. The pro rata offer is a variation of the fixed price tender offer in the US. In South Africa all share repurchases not classified as general (or open market) repurchases are referred to as 'specific repurchases'. Specific repurchases are then, according to their nature, either classified as pro rata offers or other specific offers. South African pro rata offers are similar in style to US pro rata fixed price tender offers, and South African other specific offers are similar to private (or direct) offers (Bester et al., 2010: 48).

\section{Open market share repurchases}

US open market share repurchase announcements are generally accompanied by positive returns of about $3 \%$ and long-term abnormal returns in the order of $30 \%$ over the subsequent three to four years (Ikenberry et al., 1995; Manconi et al., 2013; Peyer \& Vermaelen, 2007). Non-US open market short-term returns are generally only about half the value of those in the US; whereas long-term returns generally follow the same pattern as reported in US research (Manconi et al., 2013).

Although South African studies on the information-signalling hypothesis on announced open market share repurchases conducted by Bhana (2007), Pienaar and Krige (2012) and Wesson et al. (2014) confirmed the information-signalling theory, the results of these studies differed. Bhana (2007), who covered the period October 2000 to March 2003 in which 117 repurchase announcements were made, reported an initial abnormal return between $\mathrm{t}_{2}$ and $\mathrm{t}_{2}$ of $4,38 \%$; a long-term three-year abnormal return of $14,35 \%$; and, for value shares, a $32,8 \%$ long-term three-year abnormal return. Pienaar and Krige (2012) covered the period October 2000 to December 2007 in which 113 announcements were made by 63 companies, and confirmed the results of Bhana (2007) with a long-term three-year abnormal return of $26,57 \%$ for nonresource companies. Pienaar and Krige (2012) did not observe a conclusive result on value versus growth shares. Wesson et al. (2014) covered the period July 1999 to December 2009 in which 195 open market share repurchase announcements were made by non-resource and nonfinancial companies. The study found abnormal returns of about $-1 \%$ prior to the announcement; a small increase of about $1 \%$ surrounding the event itself (from $t_{-3}$ to $t_{3}$ ); and a maximum outperformance of about $35 \%$ on $t_{550}$ (about two years subsequent to the announcement). The outperformance was almost entirely confined to the value portfolio, reaching a maximum of about $80 \%$ by $\mathrm{t}_{600}$ (about two-and-a-half years subsequent to the announcement). The Wesson et al. (2014: 59) study applied a more robust research methodology compared to previous South African research, through using an improved dataset and extending the research period - and reported much higher abnormal returns when compared to global studies.

\section{Tender offers}

Tender offers usually entail offers made to existing shareholders in terms of a fixed price or Dutch auction tender offer. Fixed price tender offers and Dutch auction tender offers differ in the way they are structured: fixed price tender offers involve the repurchase of a pre-determined number of shares from shareholders based on a premium to current market prices, whereas Dutch auction tender offers are based on the company stating the predetermined number of shares it wants to repurchase and the price range to be considered. The purchase price is then solicited from shareholders and determined on the basis of the lowest price necessary to acquire the intended number of shares (this price being extended to all the buyback shareholders). The premium offered on fixed price tender offers is generally higher than the premium on Dutch auction tender offers (Comment \& Jarrel, 1991: 1257). Tender offers consistently outperform open market share repurchases over the short- and long-term (Vermaelen, 1981; Yook, 2010). Tender offers are viewed as a credible signal of undervaluation owing to the binding commitment to repurchase; the greater rand value involved 
(when compared to open market repurchases); the lower frequency of tender offer programmes (when compared to open market repurchase programmes); and also the fact that managers often pre-commit not to offer their shares (Ofer \& Thakor, 1987; Vafeas, 1997; Yook, 2010). Fixed price tender offers generally outperform Dutch auction tender offers, this being mainly attributable to the larger premium (when compared to Dutch auction tender offers) involved (Comment \& Jarrel, 1991).

The pro rata offer, a variation of the fixed price tender offer, offers current shareholders shares in proportion to their shareholding. Bagwell (1992) distinguished between pro rata and non-pro rata offers, by finding that it was only for nonpro rata offers that positive share returns were observed. Pro rata offers showed a price decline at expiry (exercise) date that offset the initial announcement effect - which could be explained by the marginal shareholder being unchanged subsequent to the pro rata offer (Bagwell, 1992: 88).

\section{Private offers}

Private (or direct) offers are privately negotiated repurchases from large shareholders. When a large block of shareholders wants to sell its shareholding in the market, the intended sale may negatively affect the share price and management may therefore decide to repurchase these shares directly from the shareholders. The price negotiated for the repurchase is generally lower than the market price. Private offers are seldom included in global studies, mainly because limited data are available (Vermaelen, 1981: 143). The motivation for private offers is, however, not generally associated with signalling undervaluation to the market.

In South Africa there are two private (other specific) offer types, namely: the repurchase by the holding company of shares held by subsidiaries, and other specific (or private) offers. The repurchase by the holding company of shares held by subsidiaries is a private offer which, owing to the unique characteristics thereof, should be categorised as a separate private offer category in the South African regulatory environment (Bester et al., 2010: 50). In South Africa, subsidiaries are allowed to repurchase up to $10 \%$ of the shares in their holding company (RSA, 2008), and the shares repurchased by subsidiaries represent treasury shares in the South African regulatory environment. Most countries do not allow subsidiaries to repurchase shares in the holding company and, combined with the fact that share repurchases by the holding company are not cancelled from the issued share capital in these countries, the repurchase by the holding company of shares held by subsidiaries therefore does not occur in these countries (Bester et al., 2010: 49). Companies may decide to repurchase shares through subsidiaries for various business reasons. The decision to then repurchase the shares held by the subsidiaries may, for instance, have been because the business reason that motivated the purchase by the subsidiary was no longer applicable (Wesson \& Hamman, 2012: 37). A study covering the period 1999 to 2009 reported that companies repurchasing the shares held by subsidiaries most commonly state the reason for the repurchase as being that the $10 \%$ limit has nearly been reached and, by repurchasing these shares from the subsidiaries, this would make way for new repurchases by the subsidiaries (Wesson \& Hamman, 2012). Although there was an income tax advantage for companies when repurchasing shares through subsidiaries - in the target period of the Wesson and Hamman (2012) study - and also when companies subsequently - in periods prior to 1 October 2007 - repurchased shares held by subsidiaries, it was found that companies seldom declared contentious issues (Chivaka, Siddle, Banye, Cairney, \& Shev, 2009). Secondary tax on companies (STC) was applicable to dividend and share repurchases for periods prior to 1 April 2012, after which legislation was amended to introduce a shareholder tax principle (which is generally applied in other jurisdictions).

When comparing the three specific share repurchase types in South Africa (namely the pro rata offer, and the two private offers), it was found that, for reporting periods from 1999 to 2009 , the repurchase by the holding company of the shares held by subsidiaries was the favoured specific share repurchase type (representing about $55 \%$ of total specific repurchase value), while pro rata offers and other specific offers represented about $32 \%$ and $13 \%$ of the total specific repurchase value, respectively (Wesson et al., 2015). The fact that subsidiaries are allowed to repurchase shares in their holding company has therefore affected share repurchase behaviour in the South African regulatory environment: the open market share repurchase type is not the favoured share repurchase type, and the repurchase by the holding company of shares held by subsidiaries represents about $31 \%$ of total share repurchase value - hence resulting in specific repurchases being the favoured share repurchase method (Wesson et al., 2015).

In the present study it needs to be ascertained whether the market reacts differently to the South African tender and private offer share repurchase types, and whether these reactions differ from the information-signalling effects reported in comparable global studies on different share repurchase types.

\section{Data and methodology}

\section{Population and sample}

The population for this study consisted of all companies listed on the main board of the JSE during the financial periods 1 July 1999 to the 2009 year-ends of the companies, but excluding the Basic Materials and Financials sectors. The JSE had to be the primary listing of the companies and a listing period of at least three years during the target period was required for the companies to be included in the population. The share repurchases in respect of listed ordinary and/or Nshares of the companies were included in the dataset. Odd lot offers and share trust repurchases were excluded from the sample, because odd lots have been allowed prior to 1999 and because the share trust repurchases are not treated as share repurchases in terms of the JSE Listings Requirements. 
The total population comprised 227 companies of which 55 companies made a total of 81 announcements in respect of the following tender and private offers during the target period: 15 pro rata offer announcements; 28 announcements on the repurchase by the holding company of shares held by subsidiaries; and 38 other specific offers. Appendix 1 lists the number of announcements per share repurchase type per company, and the total value for each share repurchase type.

\section{Data collection}

Data on share repurchase announcements were captured from SENS announcements of the JSE, as obtained from the Inet BFA database (product called News). Each company in the defined population of this study was individually searched using the keywords 'repurchase', 'buy-back', 'buy back', 'buyback' and 'treasury'. Each keyword needed to be searched separately, owing to the configuration of the Inet BFA database. Each SENS announcement was then captured (specifically noting the date of the announcement, number of shares repurchased and type of repurchase). The SENS announcements for each company were then reconciled with the annual report disclosures on share repurchases to ensure that announcements actually resulted in repurchases, and cumulative announcements were adjusted to exclude previously announced repurchases. The rand amounts of the repurchases were obtained from the annual report disclosures (especially the directors' reports, statements of changes in equity, and share capital notes) and/or SENS announcements. The methodology applied in the Wesson et al. (2015) study was also applied in this study to obtain share repurchase data from annual reports.

The definition of the event date for the purpose of this study relates to the JSE Listings Requirements, as stipulated in Sections 11.25 (JSE, 2007). Specific repurchases need to be announced once the terms of the arrangement have been agreed upon. The event date for all specific (tender and private) share repurchase types therefore reflected the date on which the intention to repurchase was announced, provided that the number of shares sought was included in the SENS announcement.

\section{Research methodology}

This study aimed to examine the effects that companies' share repurchase announcements of tender and private offers had on the share prices of these companies. An event study methodology was applied to test the short- and long-term market reaction subsequent to share repurchase announcements. A standard methodology for event studies has been established over time (Bhana, 1998; Bowman, 1983; Brown \& Warner, 1980; Madura \& Akhigbe, 1995) and was, broadly, also applied in this study - as discussed below.

The event date was defined as the first announcement date of the repurchase type, and this was denoted as $t_{0}$. A four-year event window was defined as 60 trading days prior to the event date to 1000 trading days after the event date and denoted as $\mathrm{t}_{-60}$ to $\mathrm{t}_{1000}$.
An important consideration for event studies, and particularly those with long event windows, is the choice of benchmark against which abnormal returns are estimated (Lyon, Barber, \& Tsai, 1999: 165). Different benchmarks have been used in other studies, for example a standard market model (Kaul, Mehrotra, \& Morck, 2000; Chen, Noronha, \& Singal, 2004; Shankar \& Miller, 2006) and a capital asset pricing model (CAPM) (Amihud \& Mendelson, 1986; Elliot, Van Ness, Walker, \& Wan, 2006; Shankar \& Miller, 2006). These benchmarks have been shown to be inadequate - the CAPM, in particular, fails to account for expected returns on the basis of company size, as well as growth versus value (Fama \& French, 1992; 1993; 1995; 1996; 1998) and resource versus non-resource shares - which is relevant especially in the South African context (Van Rensburg 2001; Van Rensburg \& Robertson 2003a, 2003b). A 12-parameter-style model to estimate benchmark returns was therefore used in this study. Following Mordant and Muller (2003), Mutooni and Muller (2007), and Ward and Muller (2010), 12 control portfolios of shares representing the cross-sectional factors of size (based on market capitalisation), growth/value (based on $\mathrm{P} / \mathrm{E}$ ratios), and resources/non-resources were constructed, and betas for each share in the sample were estimated against these. The control portfolios were rebalanced for every quarter to ensure that changes in share characteristics (market capitalisation, $\mathrm{P} / \mathrm{E}$ ratios, new listings and delistings, etc.) were closely tracked over time. Delisted shares were included up to the delisting date, after which the share price returns of the delisted companies were assumed to be zero until the end of the quarter. The delisted shares were excluded from the following quarter's rebalancing of control portfolios. Similarly, the share price returns of newly listed shares were included in the following quarter, when the control portfolios were rebalanced. Abnormal returns (ARs) for each share could then be estimated using the multiple regression equation described in Ward and Muller (2010) and Wesson et al. (2014). The performance was calculated over an extended period by accumulating the average ARs to obtain the cumulative abnormal return (CAR) for each share, over the event window period.

Owing to the non-normal return distributions generally associated with event studies, a non-parametric test to measure significance is appropriate (Ward \& Muller, 2010). In the present study a bootstrapping process was used to test ARs and CARs for significance (Noreen, 1989). Using the daily ARs for each of the shares in the sample, Monte Carlotype bootstrap distributions of CARs were constructed. This was done by selecting random dates, for each company, from the period before and after the actual event date (excluding the observations in the event window itself) and calculating the CARs. The random date generation process was repeated 200 times to generate a suite of distributions for the event window. From this data, significance levels were determined for -60-day CARs, -10-day CARs, 10-day CARs, 20-day CARs, 60-day CARs and 550-day CARs.

Although event studies typically focus on relatively short time periods, Ward and Muller (2010) argue that the use of a more sophisticated model to estimate the ARs is significantly superior to the conventional CAPM or market models, in that 
the 12 control portfolios take account of so-called style effects, including the size and value effects and the resources/non-resources dimension, known to be present on the JSE. Furthermore, the methodology of this study of constructing a bootstrap distribution of CARs across the full time-series, allowed the researchers to perform suitable significance tests for the hypotheses of this study.

\section{Research limitations}

A limitation in this research was the small number of events available for analysis. These events, however, comprise the total population for the target period of this study.

The long horizon event window extends to 1000 trading days after the effective date, however standard error limits conclusions about whether the price change is temporary or permanent.

\section{Results}

\section{Review of the data}

Table 1 shows the descriptive statistics of the 81 share repurchase announcements which were made in respect of tender and private offers during the target period (i.e. 1999 to 2009). A small number of share repurchase announcements contributed to total tender offer and private offer share repurchase value.

Although the number of share repurchase announcements in respect of other specific offers $(n=38)$ was higher than the number of announcements in respect of the repurchase by the holding company of shares held by subsidiaries $(n=28)$, the repurchase by the holding company of shares held by subsidiaries category contributed to the majority (about 51\%) of the combined share repurchase value for total tender and private offers, as observed in Appendix 1.

From Table 1 it is evident that larger companies, which were less undervalued, tended to announce large repurchases via the private offer type called the repurchase by the holding company of shares held by subsidiaries.

Table 1: Descriptive statistics on tender and private offer share repurchase announcements

\begin{tabular}{|c|c|c|c|c|c|}
\hline $\begin{array}{l}\text { Event } \\
\text { type }\end{array}$ & $\begin{array}{c}\text { Number of } \\
\text { observations }\end{array}$ & $\begin{array}{c}\text { Average market } \\
\text { capitalisation } \\
(\mathbf{R m})\end{array}$ & $\begin{array}{c}\text { Maximum market } \\
\text { capitalisation } \\
(\mathbf{R m})\end{array}$ & $\begin{array}{c}\text { Minimum market } \\
\text { capitalisation } \\
(\mathbf{R m}) \\
\end{array}$ & $\begin{array}{c}\text { Median based } \\
\text { on P/E ratio }\end{array}$ \\
\hline $\begin{array}{l}\text { Tender offer: } \\
\text { Pro rata }\end{array}$ & 15 & 8026 & 39211 & 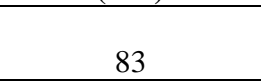 & 9,8 \\
\hline $\begin{array}{l}\text { Private offer: } \\
\text { Repurchase by holding } \\
\text { company of shares held by } \\
\text { subsidiaries }\end{array}$ & 28 & 19903 & 188534 & 23 & 11,4 \\
\hline $\begin{array}{l}\text { Private offer: } \\
\text { Other specific }\end{array}$ & 38 & 7297 & 186595 & 8 & 9,2 \\
\hline Total & 81 & & & & \\
\hline
\end{tabular}

To ensure that the results were not affected by spurious outliers, the abnormal returns were trimmed so as to exclude any daily ARs greater than $20 \%$ or less than $-20 \%$. Initially, the CARs for the full sample of events were examined across the event window from $t_{-60}$ to $t_{1} 000$, applying different weights to each observation: firstly equal weights; secondly weighted by the value of the share repurchase as a percentage of market capitalisation; and thirdly weighted by the value of the share repurchase as a percentage of market capitalisation, but with a maximum of $50 \%$ weight for any observation. Figure 1 shows that, in general, the CARs were similar, irrespective of the weighting methodology. For the data weighted by the value of the repurchase as a percentage of market capitalisation, there was evidence of influence by outliers, particularly in the first 100 days of the event window. The equal-weighted CARs were smoother and the equal weights were therefore used in the subsequent analysis.

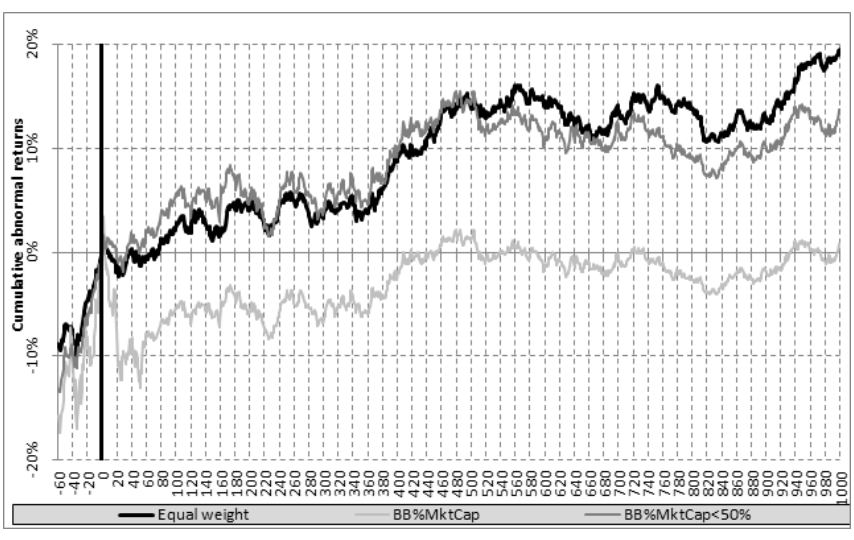

Figure 1: CARs for tender and private offer share repurchase announcements, with different weights applied to observations

\section{Significance testing}

In Table 2 the significance test results for all share repurchase types are shown, at various intervals prior and subsequent to 
the event date. The first two rows of Table 2 show the average ARs and standard error of the ARs per repurchase category, while row three represents the actual CARs of the observations of the study. The fourth row represents the $p$ value results from the Monte Carlo-type bootstrapping process. Figures in shaded blocks indicate the actual CARs which were significant (based on p values) at the 1, 5 and $10 \%$ level when compared to the suite of distributions generated in the Monte Carlo-type bootstrapping process.

The CARs of all tender and private offers were significant at $\mathrm{t}_{760}$. At $\mathrm{t}_{60}$ the CARs of all private offer share repurchase types were significant. Around the event date, at $t_{1}$ and $t_{2}$, the CARs for pro rata offers were significant; and for $t_{2}$ the CARs for the repurchase by the holding company of shares held by subsidiaries were significant. It was only in respect of other specific offers that pre-announcement CARs, namely at $\mathrm{t}-60$, were significant.

The observed results of this study pertaining to the long-term market reaction (or underreaction) subsequent to the announcement in respect of all tender and private offer types can therefore be reported as being significant (at the 5\% level - except for pro rata offers which were significant at the $1 \%$ level). The short-term market reaction around the event date of pro rata offers and the repurchase by the holding company of shares held by subsidiaries was significant on $\mathrm{t}_{2}$ at the $5 \%$ and $1 \%$ level respectively, and on $t_{60}$ a significance level of $5 \%$ was reported for the the repurchase by the holding company of shares held by subsidiaries.

Table 2: ARs, CARs and significance test results from the Monte Carlo bootstrap distributions

\begin{tabular}{|c|c|c|c|c|c|c|c|c|c|}
\hline Category & & t-60 & $t_{-2}$ & $t_{-1}$ & $\mathbf{t}_{0}$ & $\mathbf{t}_{1}$ & $\mathbf{t}_{2}$ & $t_{60}$ & $\mathbf{t}_{760}$ \\
\hline \multirow{4}{*}{$\begin{array}{l}\text { Tender offer: } \\
\text { Pro rata }\end{array}$} & Average AR (\%) & $-1,23$ & 0,05 & $-0,43$ & 1,15 & 1,05 & 0,35 & $-0,91$ & $-1,27$ \\
\hline & Standard error of AR $(\%)$ & 1,40 & 0,48 & 0,72 & 1,12 & 0,95 & 0,55 & 0,62 & 0,50 \\
\hline & Actual CAR (\%) & 0,02 & $-0,05$ & 0,00 & 1,16 & $2,22 * *$ & $2,58 * *$ & 3,24 & $-23,57 * * *$ \\
\hline & $P$ value of CAR & 0,31 & 0,49 & & 0,14 & 0,04 & 0,04 & 0,47 & 0,00 \\
\hline \multirow{4}{*}{$\begin{array}{l}\text { Private offer: } \\
\text { Repurchase by } \\
\text { holding } \\
\text { company of } \\
\text { shares held by } \\
\text { subsidiaries }\end{array}$} & Average AR (\%) & $-0,70$ & $-0,18$ & 0,53 & 0,27 & $-0,41$ & $-0,13$ & 0,02 & 1,12 \\
\hline & Standard error of AR (\%) & 0,74 & 0,57 & 0,59 & 0,85 & 0,67 & 0,37 & 0,61 & 0,51 \\
\hline & Actual CAR (\%) & $-2,59$ & 0,36 & 0,00 & 0,28 & $-0,14$ & $0,28 * * *$ & $-1,22 * *$ & $15,38 * *$ \\
\hline & $P$ value of CAR & 0,28 & 0,27 & & 0,31 & 0,35 & 0,00 & 0,03 & 0,03 \\
\hline \multirow{4}{*}{$\begin{array}{l}\text { Private offer: } \\
\text { Other specific }\end{array}$} & Average AR $(\%)$ & 0,45 & 0,63 & $-0,67$ & $-0,54$ & 0,82 & 0,90 & 0,26 & $-0,22$ \\
\hline & Standard error of AR $(\%)$ & 0,83 & 0,65 & 0,59 & 0,92 & 0,74 & 0,63 & 0,58 & 0,34 \\
\hline & Actual CAR (\%) & $-16,87 * * *$ & $-0,63$ & 0,00 & $-0,54$ & 0,26 & 1,16 & $-1,13 *$ & $34,58 * *$ \\
\hline & $\mathrm{P}$ value of CAR & 0,00 & 0,13 & & 0,19 & 0,32 & 0,20 & 0,09 & 0,01 \\
\hline
\end{tabular}

$* * * \mathrm{p}$ value less than 0,0

** p value less than 0,05

* p value less than 0,10

\section{Discussion of results}

\section{Short-term returns}

In Figure 2 the event window was reduced to $t_{-60}$ until $t_{60}$ to be able to observe the movement around the event date $t_{0}$ in detail. The only significant excess returns reported subsequent to the event were in respect of pro rata offers. These excess returns were relatively small (between $2 \%$ and $3 \%$ ) and were limited to the two days subsequent to the announcement date.

Figure 2 also indicates that the market was not efficient. The bulk of the abnormal returns occurred before $t_{0}$. The event (announcement) therefore conveyed very little new information to the market, which appears to have anticipated the announcement of the event.

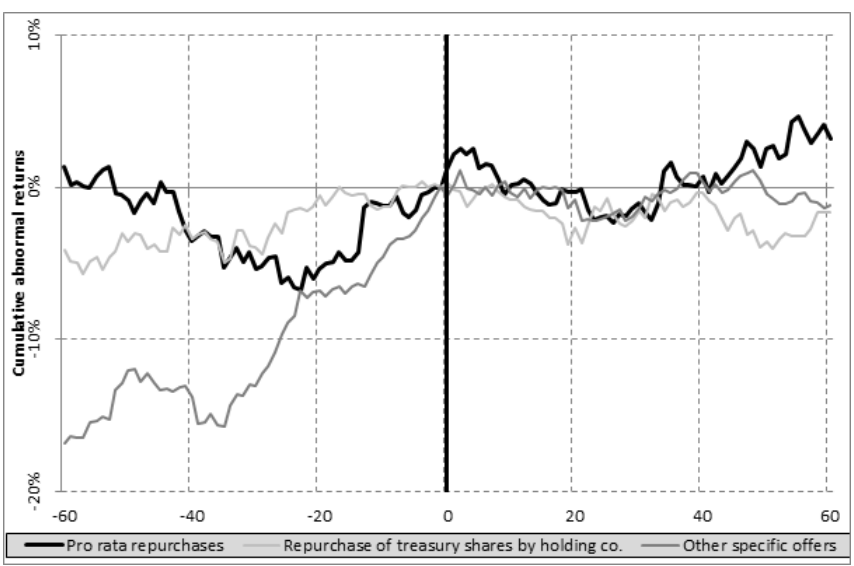

Figure 2: Short-term CARs for tender and private offer share repurchase types 


\section{Long-term returns}

As stated above, the same methodology was applied in the short- and long-term event studies. The results of Figure 3 therefore include the same results as reported in Figure 2, but over a longer event window.

Figure 3 shows that the CARs on pro rata offers were negative for most of the post-announcement period and stabilised at about $-28 \%$ on $\mathrm{t}_{780}$. The repurchase by the holding company of shares held by subsidiaries showed CARs of approximately zero until $t_{440}$, after which CARs gradually increase to about $10 \%$ on $\mathrm{t}_{560}$ (about two-and-a-quarter years subsequent to the announcement), and to about $30 \%$ at $t_{960}$ (about four years subsequent to the announcement). Other specific offers showed a steady increase as from $t_{0}$ to about $30 \%$ at about $\mathrm{t}_{480}$ (about two years subsequent to the announcement), before stabilising.

The two private offer types (namely other specific offers, and the the repurchase by the holding company of shares held by subsidiaries) showed excess returns based on the underreaction theory (i.e. over the long term), whereas their short-term returns were negative. In respect of the pro rata tender offer type, the short-term excess return evident after the event date was offset after the event date at about $t_{440}$ and an underperformance against the market was reported over the long term.

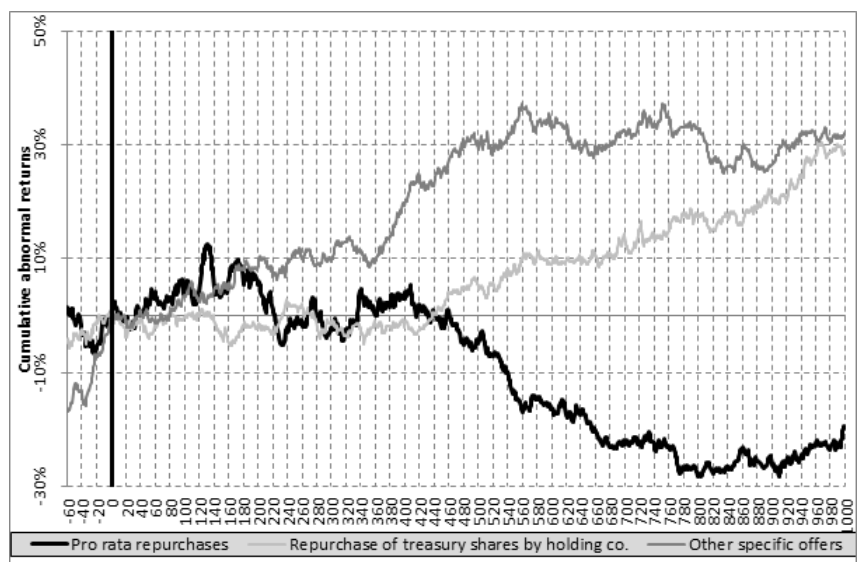

Figure 3: CARs for tender and private offer share repurchase types

As the CARs were generally stable after about three years (approximately 760 trading days), the post-event window was reduced to 760 days for the remainder of the analysis. It was only in respect of the repurchase by the holding company of shares held by subsidiaries category where an increase from about $15 \%$ to about $30 \%$ was observed over the remainder of the event window.

\section{Value versus growth}

Figure 4 shows that in respect of pro rata offers and other specific offers the value companies (namely companies with $\mathrm{P} / \mathrm{E}$ ratios lower than the median $\mathrm{P} / \mathrm{E}$ ) outperformed the growth companies (namely companies with $\mathrm{P} / \mathrm{E}$ ratios higher than the median $\mathrm{P} / \mathrm{E}$ ). The highest $\mathrm{CARs}$ values were observed for value companies conducting other specific offers (reaching a maximum value of about $40 \%$ at about $\mathrm{t}_{560}$, or about two-and-a-quarter years subsequent to the announcement, and then stabilising at that level thereafter). Value companies entering into pro rata offers showed positive CARs (fluctuating between $0 \%$ and $20 \%$ ) until about $\mathrm{t}_{550}$, after which CARs decreased to about $-10 \%$ at about $\mathrm{t}_{660}$, and subsequently increased to about $-5 \%$.

It was only for the repurchase by the holding company of shares held by subsidiaries (treasury shares) that the value companies did not outperform the growth companies - with value companies showing negative CARs till about $t_{580}$, whereafter an outperformance of about $10 \%$ was observed; and growth companies showing excess returns of about $0 \%$ till about $\mathrm{t}_{300}$, after which CARs gradually increased to around $10 \%$.

Even the growth portfolios for the private offer types (namely other specific offers and the repurchase by the holding company of shares held by subsidiaries) showed positive CARs, but at lower levels than the reported CARs for value portfolios.

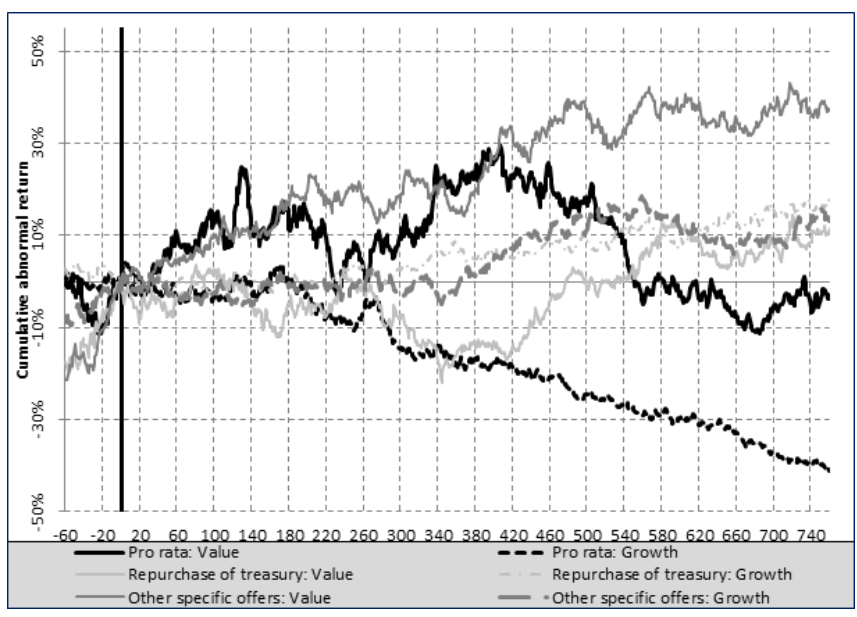

Figure 4: CARs for tender and private offer share repurchase types based on value and growth portfolios

\section{Comparison to global research on different share repurchase types}

The results reported in this study are consistent with the global results on the signalling effect of pro rata offers: the initial positive market reaction was offset over the long term. In this study only a small window of opportunity existed around the announcement date (on $t_{1}$ and $t_{2}$ ), but the observed excess return was only between $2 \%$ and $3 \%$. Value companies announcing pro rata offers did show CARs fluctuating between $0 \%$ and $20 \%$ until about $\mathrm{t}_{550}$, whereafter negative CARs were reported. Any planned investment decision based on announced pro rata offers would need to be timed correctly to benefit from the brief (and relatively small) windows of opportunity and, even then, transaction costs and market impact factors would diminish the effect of this strategy. 
Global evidence is not available on the information-signalling effect of the two private offer types (namely other specific offers and the repurchase by the holding company of shares held by subsidiaries) covered in this study. It was, however, expected that private offers in general are not executed to signal undervaluation to the market and hence would not show a significant signalling effect. This study did, however, report significant excess returns on both South African private offer types over the long term.

The other specific offer type showed excess returns of about $30 \%$ as from about $t_{480}$ (or about two years subsequent to the announcement date). When distinguishing between value and growth companies, it was found that excess returns were mainly attributable to value companies, reaching a maximum of about $40 \%$ on about $\mathrm{t}_{560}$ (or about two-and-a-quarter years subsequent to the announcement date) and the stabilising at that level thereafter. Growth companies only showed excess returns of about $10 \%$ as from about $t_{380}$. Investors will therefore benefit when investing in companies announcing other specific offers - especially if these companies are undervalued.

The repurchase by the holding company of shares held by subsidiaries type showed excess returns of about $15 \%$ at about $\mathrm{t}_{760}$ (or about three years subsequent to the announcement date), increasing to about $30 \%$ at about four years subsequent to the announcement date. When distinguishing between value and growth companies, it was however found that value companies did not outperform the growth companies: value companies showed negative returns during most of the period and the maximum outperformance for both value and growth companies was around $10 \%$ as from about $t_{580}$. The motivation for companies repurchasing shares held by their subsidiaries therefore does not seem to be the signalling of undervaluation. Investment decisions based on the information-signalling effect of announcements on the repurchase of shares held by subsidiaries will therefore not provide significant long-term benefits - especially if invested in value companies.

When comparing the results of this study to the reported information-signalling effect on open market share repurchases, it was found that the returns on South African private offers are lower than the maximum returns generally reported in respect of open market share repurchases. The most recent South African event study on open market share repurchases (Wesson et al., 2014) reported maximum excess returns of about $35 \%$ at about two years subsequent to the announcement date, and value portfolios reaching a maximum of about $80 \%$ at about two-and-a-half years subsequent to the announcement.

The important finding to be made is that not all South African share repurchase announcements convey informationsignalling benefits. Open market share repurchase announcements and the announcements on one private offer type (namely other specific offers) are followed by long-term excess returns - especially in respect of value portfolios. Information-signalling does not seem to be the motivation for the pro rata tender offer type and the repurchases by the holding company of shares held by subsidiaries private offer type. Investment decisions based on the signalling effect of share repurchase announcements therefore need to take cognisance of the regulatory environment in which the announcement was made.

\section{Conclusion}

Open market share repurchase announcements are generally associated with observed maximum excess returns reported at about three to four years subsequent to the announcement date. Globally the open market share repurchase type is the favourite share repurchase method, with the other two share repurchase types (namely tender offers and private offers) representing only about $10 \%$ of total share repurchase value. It is, however, accepted that regulatory differences between countries may explain differences in share repurchase behaviour across countries.

In South Africa the open market share repurchase type is not the favourite share repurchase method, representing only about $43 \%$ of total share repurchase value. Previous South African research on the market reaction to open market share repurchases has confirmed the signalling theory, reporting maximum excess returns at about three years subsequent to the share repurchase announcement - with value portfolios outperforming growth portfolios. The present study is the first South African study on the market reaction to announcements of tender and private offers by JSE-listed companies.

This study applied a robust research method (by following an event study methodology over a four-year event window, using a 12-parameter benchmark) to test the market reaction to announcements of the South African tender offer (pro rata offer) type and the two South African private offer types (namely other specific offers and the repurchase by the holding company of shares held by subsidiaries) of nonfinancial and non-resource JSE-listed companies over the reporting periods covering the period 1999 to 2009. The repurchase by the holding company of shares held by subsidiaries type is unique to the South African regulatory environment - and represents about $31 \%$ of total share repurchase value in this country.

The pro rata offer type has, consistently with global results, not shown long-term excess returns subsequent to announcement date. The observed results on the two private offer types differed: other specific offers showed higher excess returns (reaching a maximum of about $30 \%$ approximately two years subsequent to the announcement, and then stabilising at that level thereafter) than the repurchase by the holding company of shares held by the subsidiaries type; while value portfolios outperformed growth portfolios in respect of other specific offers (reaching a maximum of about $40 \%$ at approximately two-and-aquarter years subsequent to the announcement, and then stabilising at that level thereafter), but not in respect of the repurchase by the holding company of shares held by subsidiaries type. It was concluded that only the announcements on other specific offers were credible signals 
of undervaluation. When compared to the excess returns reported in South African research on open market share repurchase announcements, lower excess returns were observed for private offers.

The results of this study highlight that regulatory differences between countries need to be considered when evaluating the information-signalling effect of share repurchase announcements. In the South African regulatory environment, investors can benefit when investing in companies that have announced open market share repurchases, as well as other specific offers - and these benefits are more prevalent over the long term and when investing in value companies.

\section{References}

Amihud, Y. \& Mendelson, H. 1986. 'Asset pricing and the bid-ask spread', Journal of Financial Economics, 17(2): 223-249.

Bagwell, L.S. 1992. 'Dutch auction repurchases: An analysis of shareholder heterogeneity', Journal of Finance, 47(1): 71-105.

Banyi, M.L., Dyl, E.A. \& Kahle, K.M. 2008. 'Errors in estimating share repurchases', Journal of Corporate Finance, 14(4): 460-474.

Bester, P.G., Wesson, N. \& Hamman, W.D. (2010). Share buy-backs for a selection of JSE-listed companies: An exploratory study. South African Journal of Business Management, 41(4): 47-58.

Bhana, N. 1998. 'Share price reaction to announcements of equity financing by companies listed on the Johannesburg Stock Exchange', Investment Analysts Journal, 48: 35-44.

Bhana, N. 2007. 'The market reaction to open market share repurchases announcements: The South African experience', Investment Analysts Journal, 65: 25-36.

Bowman, R. 1983. 'Understanding and conducting event studies', Journal of Business and Financial Accounting, 10(4): 561-584.

Brown, S.J. \& Warner, J.B. 1980. 'Measuring security price performance', Journal of Financial Economics, 8(3): 205-258.

Chen, H., Noronha, G. \& Singal, V. 2004. 'The price response to S\&P 500 index additions and deletions: Evidence of asymmetry and a new explanation', Journal of Finance, 59(4): 1901-1929.

Chivaka, R., Siddle, A., Bayne, L., Cairney, C. \& Shev, J. 2009. 'Reasons for share repurchases in South Africa: Theory versus practice', South African Journal of Accounting Research, 23(1): 130.

Comment, R. \& Jarrell, G.A. 1991. 'The relative signalling power of Dutch-auction and fixed-price self-tender offers and open-market share repurchases', Journal of Finance, 46(4): 1243-1271.

Elliot, W.B., Van Ness, B.F., Walker, M.D. \& Wan, R.S. 2006. 'What drives the S\&P 500 inclusion effect? An analytic survey', Financial Management, 35(4): 31-48.

Fairchild, R. \& Zhang, G. 2005. Repurchase and dividend catering, managerial myopia, and long-run value destructions (Working Paper Series, 2005-21). Bath: University of Bath School of Management.
Fama, E.F. \& French, K.R. 1992. 'The cross-section of expected stock returns', Journal of Finance, 47(2): 427-465.

Fama, E.F. \& French, K.R. 1993. 'Common risk factors in the returns of stocks and bonds', Journal of Financial Economics, 33(1): $3-56$.

Fama, E.F. \& French, K.R. 1995. 'Size and book-to-market factors in earnings and returns', Journal of Finance, 50(1): 131-155.

Fama, E.F. \& French, K.R. 1996. 'Multifactor explanations of asset pricing anomalies', Journal of Finance, 51(1): 55-84.

Fama, E.F. \& French, K.R. 1998. 'Value versus growth: The international evidence', Journal of Finance, 53(6): 1975-1999.

Grullon, G. \& Michaely, R. 2004. 'The information content of share repurchases programmes', Journal of Finance, 59(2): 651-680.

Ikenberry, D., Lakonishok, J. \& Vermaelen, T. 1995. 'Market underreaction to open market share repurchases', Journal of Financial Economics, 39(2-3): 181-208.

JSE (Johannesburg Stock Exchange Ltd). 2007. JSE Listings Requirements. Service issue no. 3. Johannesburg: LexisNexis Butterworths. [Online] available: http://www.jse.co.za/listing_ requirements.jse

Kaul, A., Mehrotra, V. \& Morck, R. 2000. 'Demand curves for stocks do slope down: New evidence from an index weights adjustment', Journal of Finance, 55(2): 893-912.

Kim, J., Schremper, R. \& Varaiya, N. 2004. Survey on open market repurchase regulations: Cross country examination of the ten largest stock markets (Working Paper). San Diego State: Centre for International Business Education and Research.

Lyon, J.D., Barber, B.M. \& Tsai, C-L. 1999. 'Improved methods for tests of long-run abnormal stock returns', Journal of Finance, 54(1): 165-201.

Madura, J. \& Akhigbe, A. 1995. 'Influence of economic factors on the valuation effects of debt offerings', Applied Economics, 27(10): 907-915.

Manconi, A., Peyer, U. \& Vermaelen, T. 2013. Buybacks around the world (Faculty and Research Working Paper). Fontainebleau: INSEAD.

Miller, M.H. \& Rock, K. 1985. 'Dividend policy under asymmetric information', Journal of Finance, 40(4): 1031-1051.

Mordant, N. \& Muller, C. 2003. 'Profitability of directors' share dealings on the JSE', Investment Analysts Journal, 57: 17-32.

Mutooni, R. \& Muller, C. 2007. 'Equity style timing', Investment Analysts Journal, 65: 15-24.

Noreen, E. 1989. Computer intensive methods for testing hypotheses. New York: John Wiley \& Sons.

Ofer, A.R. \& Thakor, A.V. 1987. 'A theory of stock price responses to alternative corporate cash disbursement methods: Stock repurchases and dividends', Journal of Finance, 42(2): 365-394. 
Peyer, U. \& Vermaelen, T. 2007. 'The nature and persistence of buyback anomalies', Review of Financial Studies, 22(4): 16931745.

Pienaar, H.P. \& Krige, J.D. 2012. 'Market reaction to open market share repurchases on the Johannesburg Stock Exchange over the period 2000 to 2007', Journal for Studies of Economics and Econometrics, 36(3): 101-122.

RSA (Republic of South Africa). 2008. Companies Act, No. 71 of 2008. Pretoria: Government Printer.

Shankar, S.G. \& Miller, J.M. 2006. 'Market reaction to changes in the S\&P SmallCap 600 index', Financial Review, 41(3): 339-360.

Stonham, P. 2002. 'A game plan for share repurchases', European Management Journal, 20(1): 37-44.

Vafeas, N. 1997. 'Determinants of the choice between alternative share repurchase methods', Journal of Accounting, Auditing and Finance, 12(2): 101-124.

Van Rensburg, P. 2001. 'A decomposition of style-based risk on the JSE’, Investment Analysts Journal, 54: 45-60.

Van Rensburg, P. \& Robertson, M. 2003a. 'Style characteristics and the cross-section of JSE returns', Investment Analysts Journal, 57: $1-10$.

Van Rensburg, P. \& Robertson, M. 2003b. 'Size, price-to-earnings and beta on the JSE Securities Exchange', Investment Analysts Journal, 58: 7-13.

Van Rixtel, A. \& Villegas, A. 2015. 'Equity issuance and share buybacks', Bank for International Settlements Quarterly Review, March: 28-29.

Vermaelen, T. 1981. 'Common stock repurchases and market signalling: An empirical study', Journal of Financial Economics, 9(2): $139-183$.

Ward, M. \& Muller, C. 2010. 'The long-term share price reaction to black economic empowerment announcements on the JSE', Investment Analysts Journal, 71: 27-36.

Wesson, N., Bruwer, B.W. \& Hamman, W.D. 2015. 'Share repurchase and dividend payout behaviour: The South African experience', South African Journal of Business Management, 46(3): 43-54.

Wesson, N. \& Hamman, W.D. 2012. 'The repurchase by a holding company of treasury shares held by subsidiaries: A South African perspective', South African Journal of Business Management, 43(4): 33-44.

Wesson, N., Muller, C. \& Ward, M. 2014. 'Market underreaction to open market repurchases on the JSE', South African Journal of Business Management, 45(4): 59-69.

Yook, K.C. 2010. 'Long-run stock performance following stock repurchases', The Quarterly Review of Economics and Finance, 50(3): 323-331. 


\section{Appendix 1: Companies conducting tender and private offers}

\begin{tabular}{|c|c|c|c|c|}
\hline \multirow{2}{*}{ No. } & \multirow{2}{*}{ Company name } & $\begin{array}{l}\text { Tender offer: Pro } \\
\text { rata }\end{array}$ & $\begin{array}{l}\text { Private offer: Repurchase by the holding } \\
\text { company of shares held by subsidiaries }\end{array}$ & $\begin{array}{l}\text { Private offer: Other } \\
\text { specific }\end{array}$ \\
\hline & & $\begin{array}{c}\text { No. of } \\
\text { announcements }\end{array}$ & No. of announcements & No. of announcements \\
\hline 1 & Adcorp Holdings Ltd & & 1 & \\
\hline 2 & Allied Electronics Corporation Ltd & 1 & & \\
\hline 3 & Allied Technologies Ltd & & & 1 \\
\hline 4 & Aspen Pharmacare Holdings Ltd & & & 2 \\
\hline 5 & Aveng Ltd & 1 & & \\
\hline 6 & AVI Ltd & 1 & 1 & \\
\hline 7 & Barloworld Ltd & & 1 & \\
\hline 8 & Brandcorp Holdings Ltd & & & 1 \\
\hline 9 & Chester Investment Holdings Ltd & & & 1 \\
\hline 10 & Clicks Group Ltd & & 3 & \\
\hline 11 & Compu-Clearing Outsourcing Ltd & & 1 & \\
\hline 12 & Connection Group Holdings Ltd & & 1 & \\
\hline 13 & Control Instruments Group Ltd & & 1 & 2 \\
\hline 14 & Digicore Holdings Ltd & 1 & & \\
\hline 15 & Distribution and Warehousing Network Ltd & & & 1 \\
\hline 16 & DNA Supply Chain Investments Ltd & & & 1 \\
\hline 17 & Electronic Media Network Ltd & & & 1 \\
\hline 18 & Global Village Holdings Ltd & & & 1 \\
\hline 19 & Gold Reef Resorts Ltd & 1 & & \\
\hline 20 & Grindrod Ltd & & 2 & 1 \\
\hline 21 & Grintek Ltd & 1 & & \\
\hline 22 & Heritage Collection Holdings Ltd & & & 1 \\
\hline 23 & Imperial Holdings Ltd & 1 & & \\
\hline 24 & Invicta Ltd & & & 1 \\
\hline 25 & Kairos Industrial Holdings Ltd & 1 & & \\
\hline 26 & LA Group Ltd & & & 2 \\
\hline 27 & Metrofile Holdings Ltd & & 1 & \\
\hline 28 & MICROmega Holdings Ltd & & & 1 \\
\hline 29 & MTN Group Ltd & & & 1 \\
\hline 30 & Murray \& Roberts Holdings Ltd & & & 1 \\
\hline 31 & Mustek Ltd & 1 & & \\
\hline 32 & Netcare Ltd & & 2 & 3 \\
\hline 33 & Oceana Group Ltd & & & 2 \\
\hline 34 & Ozz Ltd & & & 1 \\
\hline 35 & Paracon Holdings Ltd & & 1 & 3 \\
\hline 36 & Pick n Pay Stores Ltd & & 1 & 1 \\
\hline 37 & Primeserv Group Ltd & & 1 & \\
\hline 38 & Prism Holdings Ltd & 1 & & \\
\hline 39 & Remgro Ltd & & 1 & \\
\hline 40 & Reunert Ltd & 1 & 1 & \\
\hline 41 & Sasol Ltd & & 2 & \\
\hline 42 & Seardel Investment Corporation Ltd & & & 1 \\
\hline 43 & Set Point Ltd & & & 1 \\
\hline 44 & Shoprite Holdings Ltd & & & 1 \\
\hline 45 & Spur Corporation Ltd & & & 1 \\
\hline 46 & Sun International Ltd & 1 & & \\
\hline 47 & The Bidvest Group Ltd & 1 & & 1 \\
\hline 48 & The House of Busby Ltd & & 1 & \\
\hline 49 & Tiger Wheels Ltd & & 1 & \\
\hline 50 & Transpaco Ltd & 1 & 1 & 1 \\
\hline 51 & Truworths International Ltd & & 1 & \\
\hline 52 & UCS Group Ltd & & & 2 \\
\hline 53 & Value Group Ltd & & 1 & \\
\hline 54 & Woolworths Holdings Ltd & 1 & 2 & \\
\hline 55 & Zarara Energy Ltd & & & 1 \\
\hline & Total number of announcements & 15 & 28 & 38 \\
\hline & Total rand value of announcements & R10 113405280 & R37 398506522 & R25 509646866 \\
\hline
\end{tabular}

